\title{
‘Old Citizenry' in a New State
}

\section{Civic Militias and Political Crises in Haarlem and Groningen in the First Half of the Nineteenth Century'}

\author{
CAROLIEN BOENDER
}

Historians have studied the regime change of 1813 in the Netherlands mainly from a national perspective, as the invented new beginning of the United Kingdom of the Netherlands. However, research on Northern Germany has shown that an urban perspective on the regime change of 1813 reveals continuities with the early modern period. The civic initiatives to preserve urban security remind of the civic commitment found in early modern corporate society. Students of the history of The Netherlands generally assume that urban citizenship withered away soon after the introduction of national citizenship in 1795 and so did the civic discourse on the importance of urban society and the civic commitment to the urban community. But did this really disappear together with the early modern political system? This article takes an urban perspective on the regime change of 1813 and studies the appearance of voluntary civic militias in Haarlem and Groningen. Their actions remind of practices and traditions of early modern civic republicanism. Was ' 1813 ' a final upsurge of practices of civic republicanism and local authority or just one example of a broader persistence of urban civic traditions in the nineteenth century?

Historici hebben de regimewisseling van 1813 in Nederland over het algemeen vooral vanuit een nationaal perspectief bestudeerd, als (een al dan niet geconstrueerd) beginpunt van het Verenigd Koninkrijk der Nederlanden. Onderzoek naar NoordDuitsland leert dat een stedelijk perspectief op de regimewisseling continuïteiten met de vroegmoderne tijd aan het licht brengt. De burgerlijke initiatieven om de veiligheid van de stad te bewaken bijvoorbeeld doen denken aan het betrokken burgerschap uit de vroegmoderne corporatieve samenleving. 
Historici veronderstellen echter over het algemeen dat in Nederland stedelijk burgerschap al snel na de introductie van nationaal burgerschap in 1795 verdween. Datzelfde zou gelden voor het daaraan verbonden stedelijke vertoog over het belang van de stedelijke corporatieve samenleving en de burgerlijke betrokkenheid bij deze gemeenschap. Maar is die breuk wel zo duidelijk? Om die vraag te beantwoorden kiest dit artikel een stedelijk perspectief en bestudeert de rol van vrijwillige burgermilities in de regimewisseling van 1813 in Haarlem en Groningen. Hun optreden weerspiegelt de praktijk van het vroegmoderne stedelijke republicanisme. Was 1813 de laatste opleving van vroegmoderne tradities of zijn er redenen om aan te nemen dat stedelijke burgerlijke tradities langer bleven bestaan?

On 25 May 1814 the locally organised National Guard (Nationale Garde), civic militias (gewapende burgermagt) and a voluntary militia of Groningen were enthusiastically welcomed back with a public ceremony on the city's central market square. ${ }^{2}$ For more than six months the National Guard and militias had been fighting the French at Delfzijl, a town in the vicinity of Groningen. Immediately after Napoleon's defeat at Leipzig peace had been restored in the western part of the Netherlands and a new state had been established. In the province of Groningen, however, it had taken months before the French troops had finally given in. ${ }^{3}$

The joyous return of the militias inspired several local poets to write celebratory poems. As one would expect, these poems praised the patriotic behaviour of the militiamen. More surprisingly is the frequent use of the terms burger (citizen) and burgerij or burgerschaar (citizenry). Wijbe Wouters for instance wrote: 'People of Groningen, sing songs of victory/As your brave citizenry/[...] returns to its fireplace and altar' ${ }^{4}$ With 'brave citizenry' (dapp're Burgerschaar) Wouters specifically meant the civic militia rather than the citizens of Groningen or the Netherlands. He was certainly not the only one.

Iwould like to thank Alle D. de Jonge, Boudien de Vries, David de Boer, Erica Boersma, Silvia Gaiga, Carolina Lenarduzzi, Thérèse Peeters and Cees Reyner for their comments on previous versions of this article. van Delfzijl in 1813 en 1814', in: Gozewinus Acker Stratingh (ed.), Bijdragen tot de geschiedenis en oudheidkunde inzonderheid van de provincie Groningen, I (Groningen 1864) 361-363.

3 Thomas von der Dunk, “'Oude partijschappen die voor altoos vergeten moeten zijn": De provincie
Groningen gedurende de omwenteling in 1813', in: Historisch Jaarboek Groningen (Assen 2001) 61-81; Busch, 'Dagverhaal van de blokkade', 224-363.

4 Wybe Wouters, Blijde welkomstgroet aan de gewapende Groningers bij hunne zegenpralende wederkomst van Appingedam en Delfzijl (Groningen 1814) 7-8; The Knuttel Collection (hereafter Knuttel) 23961; Other poems on Groningen: Knuttel 23959; Knuttel 23960; Knuttel 24057; Knuttel 23589; Knuttel 23961. 
In the Nieuwe Nederlandsche Jaarboeken, for instance, Nijmegen's civic militia of 1813 was referred to as the 'old citizenry' (oude burgerij). ${ }^{5}$

Until 1795, it had been common practice to speak of the civic militia as the 'citizenry'. Serving in the civic militia was a duty that came with the benefits connected to early modern urban citizenship. Over the centuries the institution of the civic militia had functioned as a platform to vent ideas on urban politics. The civic militia was seen as a means through which the commons were represented; this explains why civic militia were referred to as burgerij. ${ }^{6}$ In short, Wouters and others referred to the militia's responsibility to protect the urban community in an early modern way.

The fact that people like Wouters understood citizenship first and foremost in local terms may come as a surprise, considering the developments that had taken place in the decades preceding 1813. After all, during the Batavian-French period national citizenship was introduced. Moreover, since the founding of the Batavian Republic in 1795, there had been many attempts to turn the local citizen militias into a national institution. In Dutch historiography the dominant view in this regard is that advanced by Maarten Prak, who has argued that from 1795 onwards the urban corporate society fell apart and the public discourse on the urban community as a civic society withered away. ${ }^{7}$ But did this discourse and the practices of civic republicanism really disappear together with the early modern political system? In contrast

$$
\text { and Amsterdam 1814) 90, 265; Other examples }
$$
are: Johannes Enschedé, Aanteekeningen van het gebeurde in de stad Haarlem van 15 November tot 2 December van het jaar 1813 (Haarlem, approximately 1863) 6; Theodorus van Swinderen, 'Dagverhaal van het gebeurde te Groningen', in: Bijdragen tot de geschiedenis en oudheidkunde inzonderheid van de provincie Groningen, I (Groningen 1864) 319. In his correspondence the commander of Groningen's civic militia consequently wrote 'burgers' when he meant militiamen. GA, toegang 1605 , inv.nr. 415 , December 1813 .

6 Maarten Prak, 'Burgers in beweging: Ideaal en werkelijkheid van de onlusten te Leiden in 1748', Bijdragen en Mededelingen betreffende de Geschiedenis der Nederlanden 106:3 (1991) 365-393, 372.

7 Maarten Prak, Republikeinse veelheid, democratisch enkelvoud. Sociale verandering in het revolutietijdvak's-Hertogenbosch 1770-1820
(Nijmegen 1999). It is, for example, generally assumed that urban citizenship withered away soon after 1795: Maarten Prak, 'Burghers into citizens: Urban and National Citizenship in the Netherlands during the Revolutionairy Era (c. 1800)', Theory and Society 26:4 (1997) 403-420; Joost Kloek and Karen Tilmans, 'Inleiding', in: idem, Burger. Een geschiedenis van het begrip 'burger' in de Nederlanden van de Middeleeuwen tot de 21e eeuw (Amsterdam 2002) 9; Wyger Velema, 'Beschaafde republikeinen. Burgers in de achttiende eeuw', in: Remieg Aerts and Henk te Velde (eds.), De stijl van de burger. Over Nederlandse burgerlijke cultuur vanaf de middeleeuwen (Kampen 1998) 80-99, esp. 81; Ido de Haan, Het beginsel van leven en wasdom. De constitutie van de Nederlandse politiek in de negentiende eeuw (Amsterdam 2003) 93, 185; Maarten Prak and Jan Luiten van Zanden, Nederland en het poldermodel. Sociaal-economische geschiedenis van Nederland, 1000-2000 (Amsterdam 2013) 183-186. 
to most literature on the Netherlands, students of the urban history of Northern Germany have argued the opposite, showing connections between early modern and modern urban civic engagement. ${ }^{8}$ A similar approach could be of help in our understanding of Dutch history, because until 1848 the Netherlands, like Germany, had a weaker nation-state, which left room for initiatives by urban authorities and citizens. This article therefore addresses the aforementioned question by investigating 1 ) the role the persistence of early modern civic ideas played in thinking about local solutions to the national crisis of 1813; and 2) whether ' 1813 ' should be seen as a temporary upsurge of older practices or as an invitation to reconsider the nature of Dutch governance in the early nineteenth century in a broader way. ${ }^{9}$

So far the regime change of 1813 has mainly been studied as a national event and the beginning of a new era although in recent years historians have acknowledged that ' 1813 ' as a national moment of renewed adherence to the House of Orange is to a certain extent a national myth that was constructed after the event. ${ }^{10}$ I believe, however, that students of the early-nineteenthcentury Netherlands have much to gain by bridging the gap between the early modern and modern periods. One way is by exploring the urban rather than the national dimension of 1813. Because the early modern world was in many ways a local world, a local approach could unveil continuities between the two periods, rather than ruptures. In that way, it could enrich our understanding of the regime change of 1813 .

The collapse of the French regime and the withdrawal of the French troops created a power vacuum all over the Northern Netherlands: the national government was weakened, and both citizens and local governments

die 'Macht des Volkes'. Civile Ordnungsformationen und kommunale Leitbilder politischer Participation in den deutschen Staaten vom Ende des 18. bis zur Mitte des 19. Jahrhunderts (Göttingen 2000); Katherine Aaslestad, 'Cities and War: Modern Military Urbanism in Hamburg and Leipzig during the Napoleonic Era', German History 35:3 (2017) 381-402.

9 The continuities in urban civic engagement studied in this article therefore differ from 'the unmistakable legacy' of a non-political, moral and social citizenship as noted by Remieg Aerts, 'Civil Society or Democracy? A Dutch Paradox', Berichten en Mededelingen betreffende de Geschiedenis der Nederlanden 125:2/3 (2010) 209-236.

10 Matthijs Lok, "The Bicentennial of " $1813-1815$ " and National History Writing: Remarks on a New
Consensus', BMGN - Low Countries Historical Review 103:4 (2015) 111-120; Matthijs Lok, Windvanen. Napoleontische bestuurders in de Nederlandse en Franse Restauratie (1813-1820) (Amsterdam 2009); Ido de Haan, 'Een nieuwe staat', in: Ido de Haan, Paul den Hoed and Henk te Velde, Een nieuwe staat. Het begin van het Koninkrijk der Nederlanden, 9-33; Henk te Velde, 'De herdenking en betekenis van 1813 ', ibidem, $363-383$. In his thesis Bart Verheijen has challenged the construction of '1813', but he does not question the national perspective on 1813: Bart Verheijen, Nederland onder Napoleon. Partijstrijd en natievorming, 1801-1813 (Nijmegen 2017) 251-294, 299-305. Wilfried Uitterhoeve, 1813-Haagse bluf. De korte chaos van de vrijwording (Nijmegen 2013) has exceptionally taken a local approach, which is discussed by Judith Pollmann and Henk te Velde in this issue. 
took matters into their own hands. For that reason, ' 1813 ' is a suitable moment to examine continuing practices of civic engagement. Apparently, as in Groningen and Nijmegen, in several cities voluntary urban civic militias were constituted to restore peace and order. The reappearance of these militias are the central topic of this study.

I will focus on two local case studies. The first one concerns the city of Haarlem, located in the western half of the Netherlands, where the transfer of power was relatively peaceful. The second case study deals with the city of Groningen, which after November 1813 found itself in a situation of war. Allied troops partly took over local command, and military companies were marching in and out of the ramparts. The city ran out of supplies and money, in part because the French tax system was discontinued after the French civil servants had fled, taking the tax administration with them. ${ }^{11}$ Moreover, local militias faced hardships at the front because the city failed to provide them with sufficient clothing, equipment and bandages and a continuous threat came from the French sallying from Delfzijl. ${ }^{12}$ They even appeared in the vicinity of the city of Appingedam, located just 25 kilometres from Groningen, looting livestock and harvest.

The correspondence of the local governments of both cities shows how these governments tried to uphold local authority in the face of a possible return of the French troops, the interventions of the Cossacks and the establishment of the new national government. Moreover, for Haarlem I had at my disposal a rich autobiographical source written by Johannes Enschedé (1785-1866) who was in charge of 'garrison issues' in the local government in 1813. Unlike in Haarlem, the sources in Groningen did not allow me to exactly reconstruct the role of the civic militia in Groningen in the days before the return of the Prince of Orange. They did, however, provide insight into the situation during the days and months thereafter. Because these sources cover a dissimilar period, they did not enable me to compare Groningen to Haarlem systematically. However, this article does not aim to compare both cities, it rather seeks to answer a specific question on continuity for which the case studies complement each other.

In the following paragraphs of this article I will, first, provide an overview of the relevant historiographical debates. Next I will discuss the events of 1813 and explain why they are part of a tradition of early modern civic engagement. Subsequently, I will show how 1813 views on urban autonomy fit a broader pattern of resistance against increasing centralisation. Finally, I will address the question whether ' 1813 ' was a final resurgence of early modern practices of civic republicanism or just one example of a form of urban citizenship that would continue well into the nineteenth century.

GA (Groninger Archieven), toegang 1605, inv.nr. 318 (oude indeling), 'Resolutieboek, notulen 1803$1815^{\prime}$, deliberatie van 29 november 1813, 687-692.
12 GA, toegang 1605 , inv.nr. 526 , minuten van uitgegane stukken, 2 January $1813-31$ December 1813. 


\section{Civic militias in historiography}

The early modern schutterijen in the Netherlands have extensively been studied as examples of civic engagement. In his dissertation on civic militias in the province of Holland during the sixteenth and seventeenth centuries, Paul Knevel has not only explored the militia members' perception of the city and their position in the urban community but also stressed the importance of militias as platforms for political ideas. He rejected the idea that the political demands of the voluntary militias in the Patriot era were an entirely new phenomenon and marked the final disappearance of the early modern civic militias. ${ }^{13}$ Maarten Prak has elaborated this argument in his research on the upheavals of 1748 in Leiden and has shown that, because of urban civic republicanism, citizens were important political actors in times of crisis, while the civic militia functioned as a platform to vent political opinions and deliberate on petitions. ${ }^{14}$ According to Prak, the role of urban civic militias as a political force in times of upheaval has been underestimated. ${ }^{15}$ As a result, Prak concludes, the discontinuity between the early modern schutterij and Patriot exercise companies was not as fundamental as is generally assumed. These companies did not replace the schutterij and were often connected to the schutterij through its members and organisation. ${ }^{16}$

In his analysis Prak draws upon Heinz Schilling's concept of civic republicanism. According to Schilling, civic republicanism entails a set of ideas and values, shared amongst citizens, about the common good (material and immaterial) of the urban community as a whole, the privileges and duties of citizens within it and the task and responsibilities of urban government. This set was primarily politically charged and provoked political language and indirect influence by citizens. ${ }^{17}$ Civic militias, as part of urban society, were the embodiment of civic republicanism. Because militiamen were urban citizens, Militias in Late Medieval and Early Modern Europe', Past and Present 228:1 (2015) 94123. See also: Arthur Salomons, ‘De rol van de Amsterdamse burgerbeweging in de wetsverzetting van 1672', Berichten en mededelingen betreffende de Geschiedenis des Nederlanden 106:2 (1991) 198-219; Jan de Jongste, 'Dageraad der democratie? De politieke dimensie van de burgerlijke oproerigheid tijdens stadhouder Willem IV (1747-1751)', Groniek 27 (1994) 45-57, 124.

16 Maarten Prak, Republikeinse veelheid, democratisch enkelvoud, 149-153; Olaf van Nimwegen, De Nederlandse Burgeroorlog (17481815) (Amsterdam 2017) 99. Olaf van Nimwegen has argued that the Patriot exercise societies arose mainly from William v's failure to reform the army properly.

17 Heinz Schilling, 'Civic Republicanism in Late Medieval and Early Modern German Cities', in: ibidem, Religion, Political Culture and the Emergence of Early Modern Society: Essays in German and Dutch History (Leiden 1992) 3-59. 


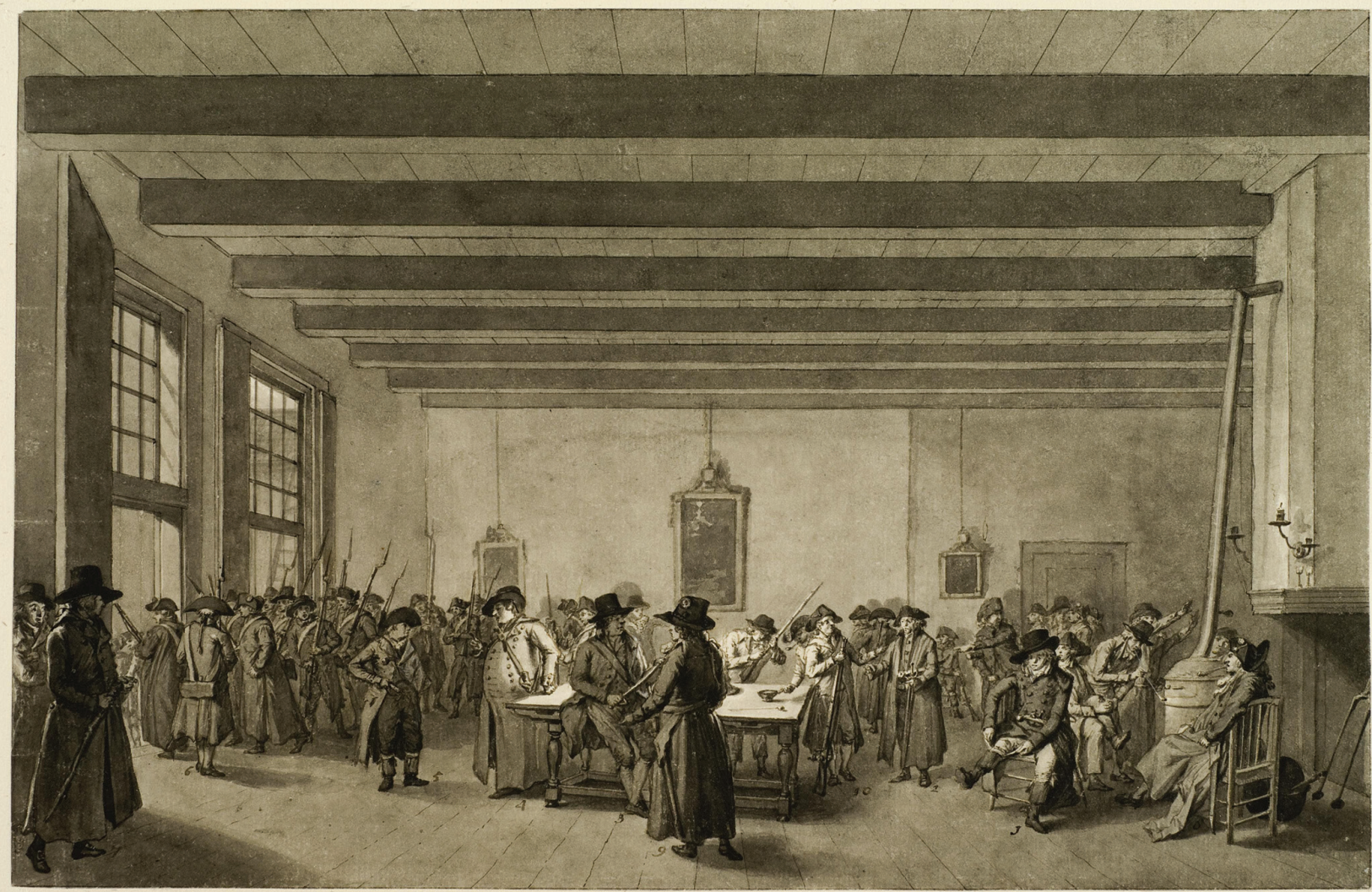

$\Delta$

Arming of the 'Burgersocieteit' (Citizen Society) of Haarlem in 1795. The figure on the left, standing in the front, is Johannes Enschedé's father. Noord-Hollands Archief/Kennemerland, Haarlem. https://hdl.handle. net/21.12102/dfdob312-fb8e-11df-ge4d-523bc2e286e2. 
the militia was seen not only as the protector of the common good but also as the representation of the commons. As a consequence, urban militias gained a strong intermediary position between citizens and the urban government. This was reinforced by the fact that militiamen were armed and actually held the monopoly on violence. This strong position enabled them to oppose the urban government and negotiate political claims if the urban government happened to forget the importance of the common good. ${ }^{18}$

It is clear that the early modern schutterij did undergo some major changes from the 1780 os onwards. After the restoration of the stadtholderian regime in 1787, the Patriot exercise companies fell apart. In 1795 the stadtholderian regime collapsed again. The new Batavian government continued to insist on the arming of citizens and replaced the early modern schutterij with a gewapende burgermagt ('armed civic troops'), a local militia that could be mobilised as a national reserve army in times of crisis. However, locally, enthusiasm for a nationally organised militia remained low, especially after the failed mobilisation of the gewapende burgermagt in 1799 during the English-Russian attack. As a result, the gewapende burgermagt continued to be locally organised. A few years later, the Batavian government picked up the threads and reorganised the gewapende burgermagt in accordance with their earlier plans. In 1806, the year Louis Napoleon took the throne, the new king only had to implement the already accepted regulation on these militias. Although the early modern schutterij had been deployed occasionally outside the ramparts, the national scale and obligatory character of the new militias aroused suspicion. People feared it was the first step towards national conscription and it provoked many protests. Because of these protests Louis Napoleon decided to rename the militias schutterij, thus emphasising that the militias were first and foremost responsible for the local peace and order. National mobilisation would take place only in times of crisis. ${ }^{19}$

Although some major changes took place in the organisation of militias, it is my contention that, precisely because of the protest against the reform of the schutterij, the resilience of practices and discourse of civic republicanism after 1795 is much greater than historians have often assumed. Though one could interpret the renaming of the militia as a form of window in het geweer, 323-367; Christopher R. Friedrichs, Urban politics in Early Modern Europe (London and New York 2000) 53-56. the renewal of the gewapende burgermagt in 1806); Christiaan van der Spek, Sous les Armes. Het Hollandse leger in de Franse tijd, 1806-1814 (Amsterdam 2016) 121-125; Johan
Joor, De adelaar en het lam. Onrust en opruiing en onwilligheid in Nederland ten tijde van het Koninkrijk Holland en de inlijving bij het Franse Keizerrijk (1806-1813) (Amsterdam 2000); Van Nimwegen, De Nederlandse Burgeroorlog, 337. On the deployment of the schutterij outside the ramparts: Paul Knevel, Burgers in het geweer. De schutterijen in Holland 1550-1700 (Hilversum 1994) 252-270. 


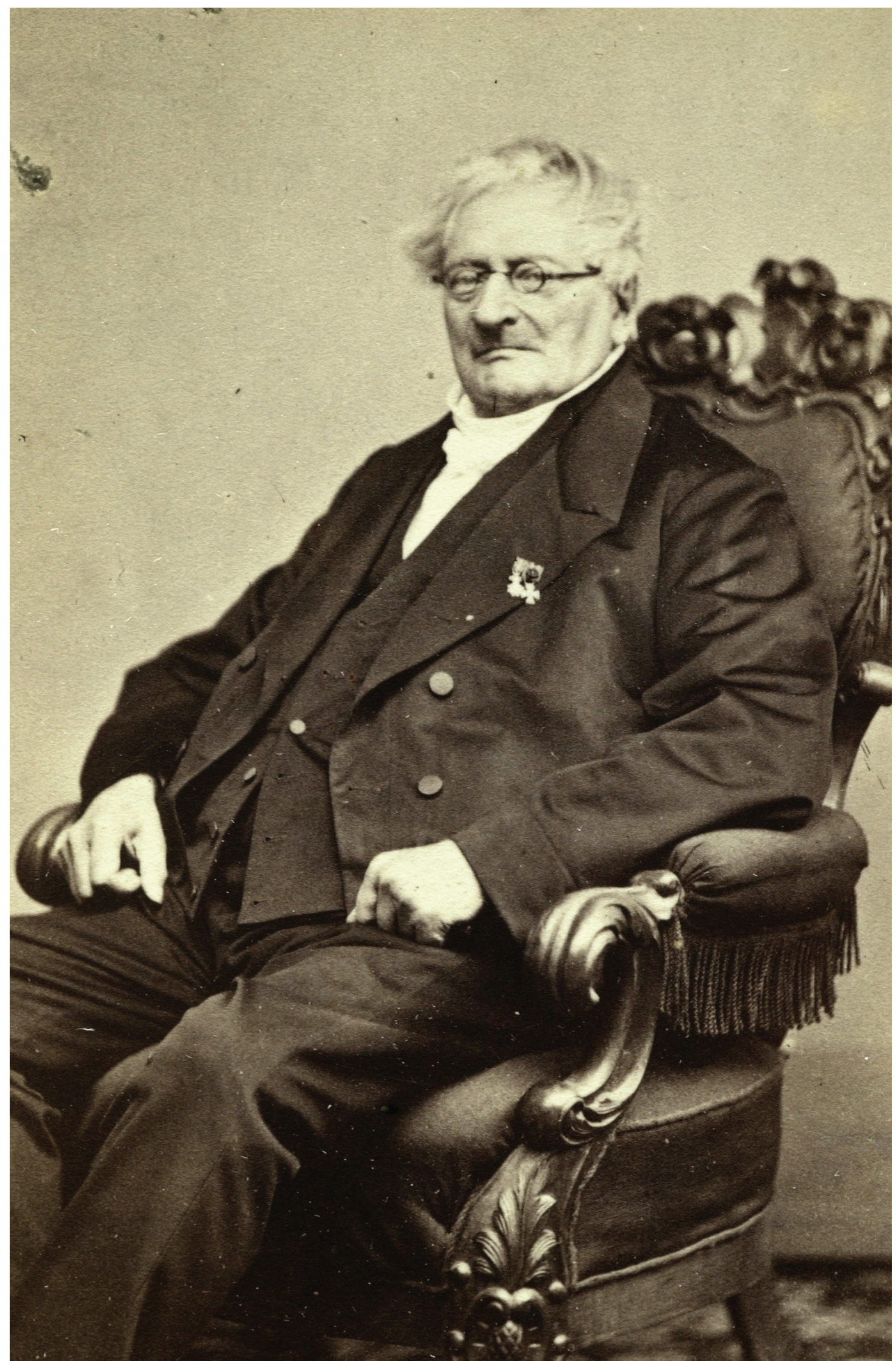

$\Delta$

Johannes Enschedé in 1864, Noord-Hollands Archief/Kennemerland, Haarlem. https://hdl.handle.net/21.12102/dfff2684-fb8e-11df-ge4d-523bc2e286e2. 
dressing, it appears that to regain local acceptance for the planned reform Louis Napoleon had to reckon with the historical background of the urban militias. In December 1813, immediately after his arrival, the Prince of Orange introduced a bill on the army and the civic militias. The bill contained Batavian and Napoleonic, but also early modern elements. The civic militias were again renamed schutterijen. Besides, the militias remained responsible for local order, but could be used for national purposes in special situations. The Prince realised that taking the militia's historical background into account would improve the local acceptance of his bill. ${ }^{20}$

Moreover, Johan Joor's work seems to suggest that the protest of citizens against the reform of the schutterijen was incited by tacit assumptions on the role and importance of civic militias for local urban communities. ${ }^{21}$ Joor argues that the old schutterij remained an important platform to mobilise protest against the French regime in $1813 .{ }^{22}$ Though after 1795 , contemporaries rather practised than theorized civic republicanism. The paramilitary interests of someone like Johannes Enschedé for example, who plays a central role in the constitution of an urban civic militia in Haarlem in 1813, evoke questions on the persistence of such practices after 1795. In the case of Enschedé, Frans Willem Lantink has remarked that 'the importance of militias for the persistence of urban consciousness [in the first half of the nineteenth century] has been overlooked'. ${ }^{23}$

Despite the above-mentioned publications, continuities in urban civic engagement after 1800 have never been a focal point in Dutch historiography. To the degree that nineteenth-century militias have been investigated, historians have mainly studied the regulations of the militias and the division of labour between civic militias and the army. ${ }^{24}$ Ben Schoenmaker has explored the opinions of army officers regarding the public debate on restructuring the army and the arming of citizens. He has pointed to the resilience of eighteenth-century Patriot and Batavian ideals in their proposals. ${ }^{25}$ However, neither the importance of urban consciousness and civic commitment nor the local roots and organisation of nineteenth-century Dutch militias have attracted much attention.

Nederlandse staat en het einde van de Zwitserse krijgsdienst hier te lande, 1814-1829 (The Hague 1988) 62-66; W.G.M. van der Heijden, NoordBrabant in de negentiende eeuw. Een institutionele handleiding (Hilversum 1993) 105-110.
23 Frans Willem Lantink, 'Een leven lang burger. Johannes III Enschedé (1785-1866)', Haerlem Jaarboek 2002 (Haarlem 2003) 72. eeuw, 105-128; Amersfoort, Koning en kanton; Ronald van der Wal, Of geweld zal worden gebruikt! Militaire bijstand bij de handhaving en het herstel van de openbare orde, 1840-1920 (Hilversum 2003).

25 Ben Schoenmaker, Burgerzin en soldatengeest. De relatie tussen volk, leger en vloot, 1832-1914 (Amsterdam 2009) 97-110. 


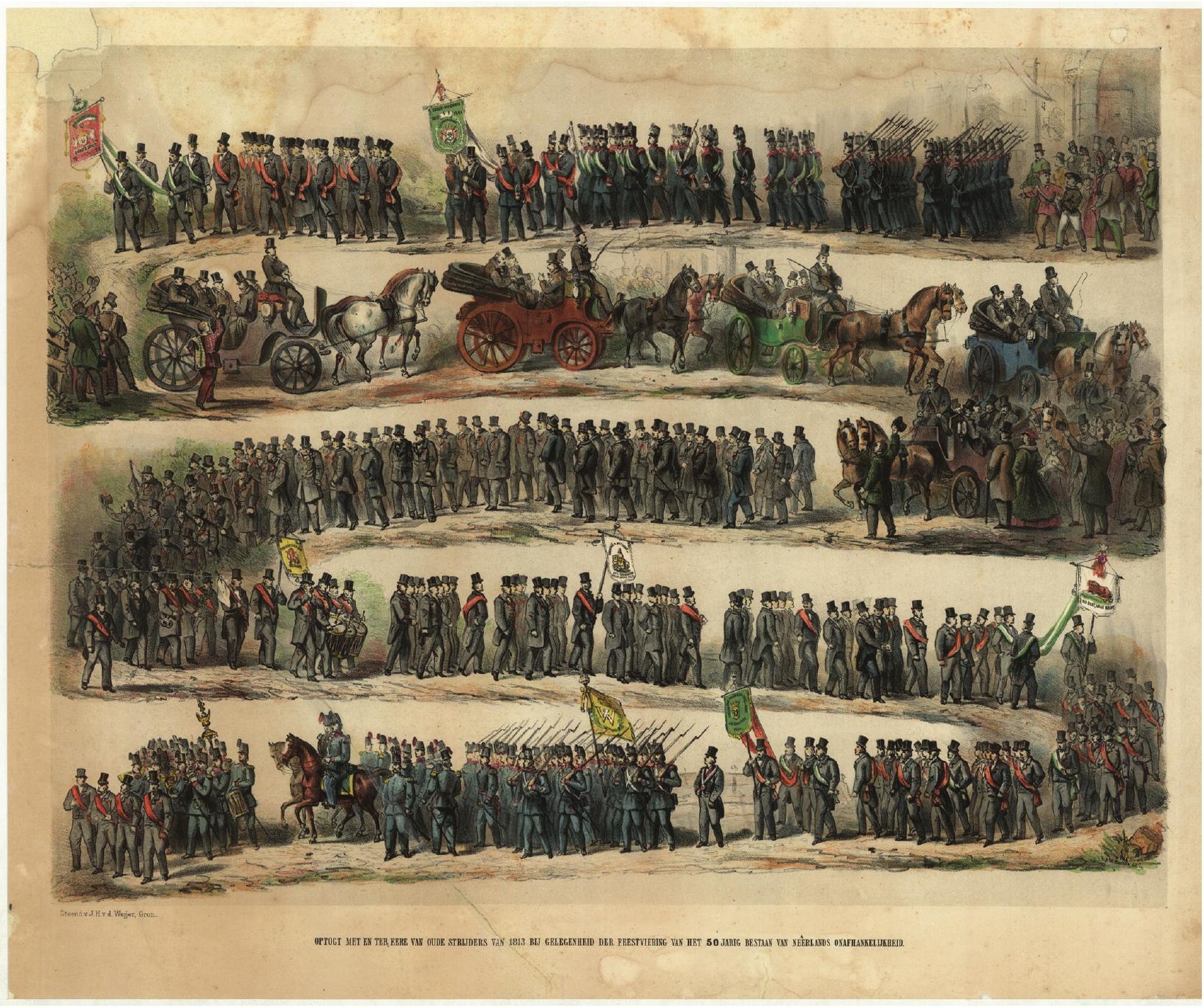

$\boldsymbol{\Delta}$

Parade of the schutterij and its veterans of ' 1813 ', celebrating the fiftieth anniversary of ' 1813 ' in Groningen, J.W. Karses, 1863. Groninger Archieven/rhc Groninger Archieven, Groningen. https://hdl.handle.net/21.12105/ec6541doc836-aeg3-3d43-gedd 2fddba71. 
Students of Dutch history could learn a lot from research on the German States in the first half of the nineteenth century. Katherine Aaslestad, for example, studied the impact of war on the urban communities of Leipzig and Hamburg between 1813 and 1815. Her work shows the resilience of urban civil society between 1800 and 1815 . In 1813-1815 for instance, in reaction to the experience of war and the infringement of local authority, citizens constituted voluntary local civic militias to defend their city and its surroundings. Such civic initiatives were set up alongside governmental initiatives. Moreover, citizens celebrated their civic engagement in commemorations and rituals. Aaslestad therefore concludes that 'cities [...] remained an important space - "a third force" - that retained its own interests and culture and mediated between the urban population and the state in times of conflict and transition' ${ }^{26}$

In a study on the political and social meaning of civic militias for the development of liberalism and civil society in early-nineteenth-century Germany, Ralf Pröve has argued that ideas on the arming of citizens blossomed in the first half of the nineteenth century precisely because these contained a mixture of civic republicanism and more modern views on politically engaged citizenship. The studies of Aaslestad, Pröve and others invite us to pose similar questions for the Dutch case, regarding the importance of civic engagement, the resilience of local authority and the persistence of early modern civic ideas. Their work gives us a hint of where continuities can be found: on the local level. ${ }^{27}$

\section{The regime change of 1813 in Haarlem and Groningen}

In 1813 Groningen and Haarlem, citizens cooperated with the urban government to safeguard the order in their local community. After several days of news about the approach of the allied troops and the passing through of French officials, the Cossacks first appeared near the ramparts of Groningen at nightfall on 14 November. That evening the prefect had announced his short leave to the mayor (maire) W.W. Jullens (1753-1819) and A.W. Senn van Basel (1783-1857). Senn van Basel was lieutenant-colonel of the local

Prove, Stadtgemeindlicher Republikanismus und die 'Macht des Volkes', 471-487; Katherine Aaslestad, Place and Politics: Local Identity, Civic Culture, and German Nationalism in North Germany during the Revolutionary Era (Leiden 2005); Katherine Aaslestad, 'Republican Traditions: Patriotism, Gender and War in

\author{
Hamburg, 1770-1815', European History Quarterly \\ 37:4 (2007) 582-602; Krista Cowman, Nina Javette \\ Koefoed and Âsa Karlsson Sjörgen, Gender \\ in Urban Europe: Sites of Political Activity and \\ Citizenship, 1750-1900 (London 2014), especially \\ section II; Michael Rowe, From Reich to State: \\ The Rhineland in the Revolutionary Age, 1780-1830 \\ (Cambridge 2003).
}


department of the Nationale Garde. In 1811, after the incorporation of the Netherlands into the Napoleonic empire, the Dutch army (NB not the local militias) merged into the French army and became the Nationale Garde. ${ }^{28}$ Because the departments of the Nationale Garde were locally based and recruited, in 1813 most cities housed a department of the Garde.

The prefect had asked Jullens and Senn van Basel to remain in their posts until his return and immediately after his departure the gates of the city had been shut. ${ }^{29}$ Subsequently, the militiamen, members of the local militia gewapende burgermagt, had taken off their French cockade. The following morning Cossacks reappeared and the colonel of the gewapende burgermagt, Marcus Busch (1769-1843) and Senn van Basel decided to open the city gates and let them in, without consulting the mayor. ${ }^{30}$ Although this caused some changes in the department's civil service, most of the local officials remained in office. The gewapende burgermagt and Nationale Garde almost immediately marched out to fight the French troops at Delfzijl.

Haarlem saw a somewhat different role of the civic militia in the regime change of 1813. In Haarlem a militia was constituted by the mayor of the city, Willem Philip Barnaart (1781-1851), who was officially in service of the French government. On 16 November, he sent for Johannes Enschedé and asked him to secretly deliberate on the city's public security. He commanded Enschedé to set up a civic militia, an order that contravened the rules of French government. This was not without danger, as a French garrison and a French department of gendarmes were still in the city. ${ }^{31}$

Enschedé invited six men to serve in the militia as captains and ordered them to appoint some 'of the most reliable' men as their subordinates and wait until his sign for action. ${ }^{32}$ On 18 November a second meeting took place between the maire, Enschedé and the commander of the French troops who had announced that he would leave the city. During that meeting Barnaart asked Enschedé whether he was able to secure order and obedience to the French emperor. Enschedé said no and asked the maire to resign from office. Next, he decided to appoint a provisional urban government together with his captains and ordered these new officials to be present at the city hall early next morning. One of the six departments was sent to the doelen, the meeting room of former civic militias, to await the moment of withdrawal by the French troops. Immediately after their withdrawal, the city gates were shut and the new civic militia patrolled the city walls and neighbourhoods. After a new urban government had been nominated by Enschedé in his notulen 1803-1815, inv.nr. 318, deliberatie van 15 november $1813,683-686$. altoos vergeten moeten zijn', 62, 71-72; Van
Swinderen, 'Dagverhaal van het gebeurde te Groningen', 319.
31 officers. 
capacity as chief of the civic militia, it was elected by the captains, and installed in a joint meeting of the civic militia and the members of the new government. ${ }^{33}$ Most of the 'new' urban officials, except the mayor, had already been members of the previous government, and thus remained in office. ${ }^{34}$

In short, in both Haarlem and Groningen the civic militia had a decisive role in the regime change. Unlike in Groningen, in Haarlem an entirely new militia was constituted which would take over local command. In Groningen, on the other hand, the gewapende burgermagt cooperated with the local company of the Nationale Garde. Officially the militia's task was to safeguard local order. Yet the Guard clearly felt responsible as well. Though both in Haarlem and Groningen the militias had a central role in the regime change, the size of this role was dictated by the local situation.

\section{Early modern roots}

By looking at Enschedé's memoirs of 1813, it becomes clear that these local differences were not entirely coincidental. In his memoirs he pays a lot of attention to seemingly negligible details of the constitution and role of the militia in Haarlem. Yet when studied in the light of early modern civic republicanism, these details take on a new meaning.

First, Enschedé discusses in detail the composition of the new civic militia. To organise it he used the structure of the six wijken, a division of the city into various districts. The early modern schutterij had always been organised along these wijken, though the number of districts had varied over time. In the seventeenth and eighteenth centuries every wijk had four vendels, or companies. ${ }^{35}$ Enschedé appointed one captain in every wijk, who commanded one company. He thus built upon the former structure of the early modern schutterij, but did not fully restore it. His decision was made easier by the fact that, although the old schutterij had been formally disbanded for a few decades, in practice, it was not dismantled until early $1813 \cdot{ }^{36}$

Next, Enschedé extensively describes the militia's search for weapons and ammunition. For a civic militiaman, it was important to at least bear some sort of weapon. However, because of the dismantlement of the schutterij and the disarmament of the local department of the Nationale Garde, few

Enschedé, Aanteekeningen, 6-12.

As a general comparison of the Opregte

Haarlemsche Courant (20 November 1813, nr.2)

and biographical information suggests. I would

like to thank Alle D. de Jonge for sharing his

knowledge and database (Collectie De Jonge) on

Haarlem's elite in the eighteenth century.
35 Jan de Jongste, Onrust aan het Spaarne. Haarlem in de jaren 1747-1751 (Haarlem 1984) 117.

36 Martinus Bruijel, 'Haarlem in 1813', in: Gijsbertus Koolemans Beijnen (ed.), Historisch gedenkboek der herstelling van Neêrlands onafhankelijkheid in 1813, deel II (Haarlem 1913); Enschedé, Aanteekeningen, 5 . 
weapons could be found in the city of Haarlem. Some militiamen used old pikes and lances of the drama society 'Leerzaam Vermaak', whereas others visited the local blacksmiths in search of arms. ${ }^{37}$ As a pike from a drama society might not be the best weapon to fight the enemy, there must have been more at stake here. Apparently, displaying arms clearly marked that the monopoly of violence was possessed not by the French government nor by the official urban government but by the citizens of Haarlem who retained the right to defend themselves. Their behaviour recalls the older ideal of the armed citizen as the protector of the common good and the restorer of civic freedom: one of the foundations of the schutterij in the Middle Ages that again had bloomed during the Patriot era in the second half of the eighteenth century. ${ }^{38}$ The importance Enschede ascribed to the arming of the civic militiamen shows that this ideal was still alive in 1813. Indeed, as I have discussed in the introduction of this article, in Groningen too the actions of voluntary civic militias were legitimised by referring to the armed citizens as protectors of the common good. However, according to Enschedé, the arming of citizens functioned only within an institutional framework. If not, it would endanger public order. In Beverwijk, for example, several citizens armed themselves with weapons that were sold by deserting French soldiers. As a result, Enschedé and the maire of Beverwijk did everything possible to prevent this from happening. 39

Enschedés description of the election and appointment of the lieutenants too acquires more meaning in light of early modern civic republicanism. After their appointment by Enschedé, the lieutenants gathered a few of 'the most reliable residents' in their own wijk, who in turn officially elected their superiors by 'common agreement'.$^{40}$ This course of events honoured the early modern tradition of the officer picking his subordinates in his own wijk. ${ }^{41}$ However, the subsequent election of officers by their subordinates was not a self-evident tradition. After the Dutch Revolt, urban governments obtained the right to appoint the militia's officers, a measure aimed at restricting the political influence militias had gained during the Revolt. This restriction had been one of the main points of conflict during the civic uprisings of 1672 and 1748 in the Netherlands. ${ }^{42}$ According to the protesting militiamen, the right to appoint officers from their own ranks would re-establish their independent position. Although Enschedé does not explain why he chose to revive this tradition, the very fact that he explicitly

toegang 3993, inv.nr. 313, Missiveregister

(afschriften van uitgaande stukken), letter to the

maire of Beverwijk, 21 November 1813 (no number available).
40

41

42
Enschedé, Aanteekeningen, 7.

Knevel, Burgers in het geweer, 190.

Prak, 'Burgers in beweging', 371-372, 378; De

Jongste, Onrust aan het Spaarne, 117-223; Knevel,

Burgers in het geweer, 190. 
mentions this officer election shows his awareness of the tradition and the importance he attached to an independent civic militia.

In addition, Enschedé also explicitly addresses the election of the urban government by the elected officers. This is another example of a mixture of already existing early modern practices and the realisation of early modern quests for reform. As we have seen, Enschedé, in his capacity as chief of the civic militia, nominated the members of the new urban government. The officers then officially elected these members, after which they were installed in a joint meeting with the civic militia. ${ }^{43}$ In other cities, such as Amsterdam and Middelburg, the urban government was also nominated and appointed by the civic militia. ${ }^{44}$ Although Groningen did not see an election of a new urban government by militiamen, the chiefs of the militias were the ones who decided to open the gates and let the Cossacks in, which illustrates their powerful and independent position during the regime change. 45

On the one hand, this political influence of armed citizens on the urban government reminds us of earlier political demands by civic militias. During the Dutch Revolt, in some cities representatives of the civic militia were in charge of electing a new urban government. ${ }^{46}$ Although in later years their political power was successfully limited, the influence of the militias on local politics remained, especially during political upheavals. In 1748, for instance, militias throughout the Netherlands expressed their political demands, like the wish to monitor the city's finances by a committee of citizens. After the urban government declined to honour their requests, the militias in Leiden and Haarlem explicitly pressed for a replacement of the urban government (wetsverzetting) by refusing to execute their tasks. ${ }^{47}$ Thus, as Schilling and Prak have argued, early modern militias were well aware of their influence on urban politics. In that way, the civic militias of 1813 stood in an age-old tradition of overthrowing an urban government that ignored the common good..$^{48}$

On the other hand, the election of the new government by the civic militia in 1813 shows the influence of the Patriot era. In this period, in Haarlem a proposal was drafted to give armed citizens influence on the

Swinderen argues that good urban governance (an antonym of French governance) and proper civic behaviour would save the Netherlands. Though it is addressed to all citizens of the Netherlands, it very much reflects the local events: Theodorus van Swinderen, Een woord op zijn tijd aan de Nederlanders bij het verlaten van hun grondgebied door de Fransche troepen (Groningen 1813).
Enschedé, Aanteekeningen, 12; Opregte Haarlemsche Courant, 20 November 1813, nr. 2, 1. nr. 5,1 .

Von der Dunk, 'Oude partijschappen', 72.

Prak, 'Citizens, soldiers and civic militias', 119.

Prak, 'Burgers in beweging', 386-387.

Rudolf Dekker, Holland in beroering. Oproeren in de 17e en 18e eeuw (Baarn 1982); Prak, 'Burgers in beweging', 365-393; In a pamphlet Theodorus van 
composition of the urban government by indirect election. ${ }^{49}$ As a result of the restoration of the stadtholderian regime in 1787 , it was never implemented. However, Enschedé was probably well aware of this earlier proposal, especially because his father had been one of the leading figures in the Patriot movement of Haarlem. His description of the election process also shows that he endorsed the political influence of armed citizens on local politics. For him, the explicit election of the urban government by representatives of the urban community legitimised its power.

In short, one could argue that Enschedés solutions to the mounting crisis remained very local. Moreover, his organisation of the civic militia followed several traditions from the early modern schutterij and from Patriot exercise societies. We can therefore conclude that Enschedés solutions very much breathed civic republicanism.

\section{Local authority and urban self-confidence}

The natural way in which urban governments and citizens in 1813 relied on previous local traditions of crisis management should be seen in light of an ongoing struggle over the preservation of local autonomy that had originated in the Batavian Era. ${ }^{\circ}$ This struggle manifested itself especially in the years around the abolition of the urban corporations, such as the civic militias and the guilds. For ages access to these institutions had been regulated by urban citizenship which was available only to a select group of inhabitants. Batavian radicals described this barrier as contradictory to the equality of men and therefore from 1795 onwards the National Assembly made serious attempts to dismantle the early modern corporations. Not surprisingly, the representatives of the National Assembly found strong and confident civic institutions in their way. ${ }^{51}$ In 1813 similar conflicts arose between the new general government (algemeen bestuur) in The Hague and the cities of Haarlem and Groningen. 118-122; Jan Woltjer, 'Dutch privileges, real and imaginary', in: John Bromley and Ernst Kossmann, Some political mythologies: Papers delivered to the fifth Anglo-Dutch historical conference, Britain and the Netherlands v (The Hague 1975) 19-35; Prak, 'Burgers in beweging', 365-393; Knevel, Burgers in het geweer, 368-378. About Haarlem: Niek van Sas, De metamorfose van Nederland. Van oude orde naar moderniteit, 1750-1900 (Amsterdam 2004) 182.

Pepijn Brandon and Karwan Fatah-Black,

“"The supreme power of the people": Local
Autonomy and Radical Democracy in the Batavian Revolution (1795-1798)', Atlantic Studies - Global Currents, 13:3 (2016) 370-388; Thomas Poell, The Democratic Paradox: Dutch Revolutionary Struggles over Democratisation and Centralisation (17801813) (Unpublished PhD Dissertation, University Utrecht, 2007).

51 NHA, toegang 1105, Gildenarchieven, inv.nr. 378, 'Notulen der vergaderingen, 1795-1798'; Nico Slokker, Ruggengraat van de stad. De betekenis van de gilden in Utrecht, 1528-1818 (Amsterdam 2010). 
After the establishment of the algemeen bestuur, Van Hogendorp immediately started to gather the remaining weaponry in the Netherlands. One of his delegates, H.L.F. Eichholtz, was sent to Haarlem around 23 November, because the algemeen bestuur had heard that some boxes with weapons were hidden in the house of the assistant-prefect. ${ }^{52}$ Johannes Enschedé, as chief of the civic militia, denied this rumour, and sent Eichholz back stating that he had no official affirmation that a new algemeen bestuur had been established in The Hague. Thereupon, Van Hogendorp wrote the urban government of Haarlem a letter dripping with sarcasm: 'As you may have noticed from the various and several publications in name of the Prince we have established an algemeen bestuur'. The second time Eichholz was sent to the city, Enschedé again refused to hand over the few weapons. This time he claimed that, among other things, it would weaken the city's position against the withdrawing French troops. Van Hogendorp got angry; in a second letter he commanded the city of Haarlem to accept the status of his delegate and threatened the city with severe consequences 'when the prince arrived'. ${ }^{53}$ The urban government of Haarlem was not impressed.

Yet Haarlem was not the only city that dared to oppose the algemeen bestuur. Because the city's local civic militia had marched out to fight the French at Delfzijl, in Groningen, in contrast to Haarlem, the power was mainly in the hands of maire Jullens. It took days before the news of the establishment of the algemeen bestuur reached the city. A delegate was sent to Groningen. He tried to persuade the local government to wave the orange flag as it was forbidden to wear an orange sash or ribbon. Because it took a while before the ban on wearing orange was lifted, some historians have pointed to the lack of orangism of the urban government of Groningen. ${ }^{54}$ Others have argued that this independent behaviour of cities such as Haarlem and Groningen stemmed from fear of the French troops. ${ }^{5}$ It is true that both Haarlem and Groningen wanted to maintain a more or less neutral position as long as there was no clear new national political framework and the French might be able to march in again. However, if we consider the urban governments' courage in opposing the algemeen bestuur and the fact that cities still had the institutional structure in place to immediately organise a militia, it is more likely that cities still thought it was their right to maintain peace and order on the local level. In the eyes of both the civic militiamen and the urban governments in this case the local superseded the national. authentieke stukken, oktober-december 1813, Kemper en Fannius Scholten aan het stadsbestuur, 25 november 1813 , nr. 51.
46; NHA, toegang 3993, inv.nr. 209, brief van Gijsbert Karel van Hogendorp, 24 November 1813, nr. 49 . Uitterhoeve, 1813-Haagse bluf, 249, 359, 360; Von der Dunk, 'Oude partijschappen', 63. Lok, Windvanen, 51 
However, this explanation ignores the urban civic pride that echoed in the language of urban governments and citizens, and it does not explain why for instance mayor Jullens of Groningen constantly felt the need to demarcate his right to oppose both provincial officials and the members of the algemeen bestuur. ${ }^{56}$ A more convincing explanation can be found in the aforementioned struggle over local authority. Local officials felt that the dominant behaviour of the algemeen bestuur in The Hague should not limit their own city's room for independent decisions. Therefore Van Hogendorp's initiative was treated with distrust.

That this behaviour was rooted in local pride is highlighted by the fact that the urban governments of Haarlem and Groningen treated other supralocal powers with the same self-confidence as they did the algemeen bestuur. In Groningen the commander of the Cossacks, Baron Rosen, immediately took over the local military, civil and legal power. In addition, he attempted to regulate the city's finances. His behaviour was considered to be disrespectful to the traditions of local authority, whereupon the urban and provincial government tried to stop him. ${ }^{57}$

The urban government of Haarlem treated the French government with similar confidence. On 19 November, assistant-prefect (onder-prefect) Ewout van Vredenburch circulated a personal note in which he accused the city of Haarlem of rebellion against the French government and stated that the riots had caused him to leave the city and resign from office. Former Maire Barnaart, who had already resigned from office, wrote him a letter 'on behalf of the 20,ooo people living in Haarlem' to express his disbelief and grief about the assistant-prefect's statements. According to the former mayor, the assistant-prefect harmed the city's reputation because no riots had taken place, or at least nothing he would qualify as a riot. The former mayor then pressed the new provisional urban government to send his letter to the assistant-prefect. ${ }^{58}$ Thereupon the new provisional urban government told the assistant-prefect not to compromise the age-old good name of the city of Haarlem. ${ }^{59}$ Both the mayor's and the urban government's arguments were dictated by civic pride. The former mayor emphasised for instance the spotless reputation of Haarlem: the inhabitants of Haarlem had always been orderly people and would continue to be so. ${ }^{60}$

Besides civic pride, the mayor's critique of the attitude of the assistant-prefect demonstrates clear ideas about proper governance and local authority. According to the mayor, the assistant-prefect resigned at the

uitgegane stukken, 2 January 1813-1831 December 1813, especially the letters from December 1813.
$59 \mathrm{NHA}$, toegang 3993, inv.nr. 313, letter to the assistant-prefect, 22 November 1813, (no number available).

$60 \mathrm{NHA}$, toegang 3993, inv.nr. 313 , letter to the assistant-prefect, 22 November 1813, nr. 875. 
moment his position became shaky, but also when the danger of chaos was the greatest. Instead of managing the crisis, the assistant-prefect tried to save his reputation by accusing the city of Haarlem, which according to the mayor endangered the security of the city. Because the community of Haarlem could not defend itself against the insults of the assistant-prefect reprisals by the French had to be feared. Moreover, unlike the mayor, who had taken measures, the assistant-prefect had refused to give any orders to prevent disorder. The assistant-prefect did not sacrifice his position for the sake of the urban community as the mayor himself had done after the establishment of a new provisional urban government. ${ }^{61}$ The mayor's judgement of the assistant-prefect's behaviour reflects his ideal type of governor, someone who would rather deny himself than the common good of urban society, which we recognise as an ideal type from early modern civic republicanism. However, it also shows that in his eyes urban governors should and could independently make decisions regarding local order.

To conclude, in this precarious moment of transition, cities instantly fell back on a long-standing institutional experience of local solutions to national crisis, rooted in the old regime of the Dutch Republic. Besides, cities used this moment to secure their local autonomy against supra-local powers. Moreover, to ensure the continuity of daily life in the city the urban governments of Haarlem and Groningen could not await national measures, but immediately had to take action. Taxes were collected, French officials replaced and church services on Sunday reintroduced. ${ }^{62}$

\section{3 the last upsurge?}

The question arises whether ' 1813 ' was a final upsurge of practices of civic republicanism and local authority or just one example of a broader persistence of urban civic traditions in the nineteenth century. At first glance, one might argue that the nineteenth-century Netherlands did not experience any comparable crises with such an independent position for cities. Yet, two other imminent crises followed later in the century: the Belgian Revolt of 1830 and the revolution of 1848 . A short exploration of these two moments demonstrates that, once seen from a local perspective, these crises also resemble urban forms of civic engagement. In that way, some striking similarities with 1813 appear.

In 1830 riots in the city of Brussels in the Southern Netherlands soon developed into a full-blown revolution to secure the independence of Belgium. The imminent separation of the Northern and Southern assistant-prefect, 22 November 1813, nr. 875.
December 1813, especially November and December 1813; NHA, toegang 3993, inv.nr. 313, missiveregister 1813 , especially November and December 1813 . 
Netherlands caused a wave of nationalism in the northern part of the country. ${ }^{63}$ However, a local, urban perspective demonstrates that this nationalism was founded on local pride and local voluntary initiatives.

For many cities in the northwest and northeast of the Netherlands the fights in the south near Brussels did not pose an immediate threat. The regular militias (schutterij) from northern parts of the country therefore were mobilised and marched to the south to assist King William I's army. However, civic militias from cities in North-Brabant and Zeeland were mobilised to protect their own communities. ${ }^{64}$ Northern militias thus crossed local borders and fought for a national aim, as was laid down in the law on the militias. In NorthBrabant and Zeeland militias also stayed home to preserve local order and peace. In addition to the regular militia several voluntary initiatives emerged, as was the case in 1813. Students in Leiden and Utrecht for instance organised themselves voluntarily and went to the south. ${ }^{65}$ Thus not only was the regular militia locally organized, but also the voluntary initiatives were locally born.

The same interplay between national and local pride and national and local organisational structures can be found in the immense number of poems praising the actions of the militias of 1830 . Most of them were written for a specific company from a specific city. Titles for instance said: 'For the civic militia marching out of Den Bosch' or 'On the returning of the militia of Zutphen'. Although, as in 1813, these poems contained many references to the honour of fighting for the fatherland, militiamen were often encouraged with references to the city's heroic history. Several poems refer to the actions of the city's civic militia during the Dutch Revolt. ${ }^{66}$ As in 1813, the bravery of the civic militia was also celebrated in the local community. In Rotterdam women sewed a banner for the militia, whereupon poems were dedicated to this feminine engagement in the honouring of 'our city at the Meuse'. ${ }^{67}$ Moreover, local festivities and public ceremonies were organized to celebrate the return of the civic militias. ${ }^{68}$

During the revolutionary year 1848 , the national government fell back on this longstanding tradition of urban voluntary initiatives. The Minister

63 Niek van Sas, 'Het Grote Nederland van Willem I. Een schone slaapster die niet wakker wilde worden', in: ibidem, De metamorfose van Nederland. Van oude orde naar moderniteit 17501900, 401-411, 408.

64 Paul Consten on the civic militia of Goes in his forthcoming thesis on I.D. Fransen van der Putte.

65 Jacqueline Bel, Willem Otterspeer and Peter Zonneveld, De Leidse jagers 1830-1831. Studentvrijwilligers en de Belgische Opstand (Leiden 1981). Knuttel 26181; Knuttel 26459.

67 Knuttel 26474; Knuttel 26462.

68 In Groningen the return of the militiamen was extensively celebrated: CA, toegang 1399, inv.nr. 10991, 'Stukken betreffende de terugkomst van het bataljon mobiele Groningse schutterij uit het leger, 1834'; Local associations contributed to the festivities: GA, toegang 1733, 'Boekverkoperscollege, 1784-1990', inv.nr. 1, 'Notulen van vergaderingen, 1815-1834', 1830. 
of Justice ordered the provinces to command the urban governments in their region to organise a militia of volunteers, 'burgers', to prevent disorder. ${ }^{69}$ The minister thus immediately thought of a local solution for this impending national crisis. As a result, the governor of the province of Groningen wrote a letter to the urban government of Groningen and ordered them to gather some reliable ('vertrouwde') men to secretly deliberate on the issue of protecting their community should disorder arise - just as the mayor of Haarlem had done in 1813. The governor's selection criteria were remarkable: reliable men were 'inhabitants who, according to their social position would have an extraordinary interest in the maintenance of peace and order, or inhabitants with influence'. ${ }^{70}$ Groningen's governor presupposed an interest in urban society only by a select group of men. According to him, the willingness to serve the urban community depended on one's position in urban society. Both criteria remind us of the ideals on the engagement of citizens with their urban community discussed in this article. ${ }^{71}$

In short, the crises of 1830 and 1848 point to the power of urban consciousness and civic engagement in the first half of the nineteenth century. Moreover, these two examples invite us to continue to study the influence of early modern forms of civic engagement on Dutch society and governance in the nineteenth century. After all, similar questions could be asked with regard to other urban corporations. Joost van Genabeek has pointed to the resilience of the Dutch guild system because of the central state's inability to replace the system's economic-social functions in urban society. ${ }^{72}$ However, the role of civic commitment in the resilience of guilds has not gained much attention. Neither did King William I's proposal to reintroduce the guild system, and the enthusiasm it met from urban governments and the still existing guilds. ${ }^{73}$

69 Matthijs van de Waardt in his forthcoming thesis on Dirk Donker Curtius.

GA, toegang 1399, inv.nr. 6034, 'Maatregelen genomen bij ordeverstoringen ten gevolge van de februari-revolutie in Frankrijk'. Letter from the 'staatsraad, gouverneur van de provincie Groningen' to mayor and alderman (wethouder) of the city of Groningen, 4 maart 1848. 1861 saw a massive revival of local voluntary shooting societies stemming from the feared attack by Prussia. Ben Schoenmaker has shown how these militias were inspired by two earlier traditions: on the one hand, the Patriot and Batavian militias (an inspiration for more liberal citizens) and, on the other hand, the volunteers of $1830 / 1831$ (an inspiration for the more conservative, monarchist movement); Ben Schoenmaker, Burgerzin en soldatengeest, 107. st van Genabeek, 'De afschaffing van de gilden en de voortzetting van hun functies', in: NEHAjaarboek 57 (1994) 63-90. The mayor of Groningen responded enthusiastically and offered an extensive proposal on the reintroduction of the guild system: GA, toegang 1605 , inv.nr. 527, letter of 30 Augustus 1814, nr. 253; See for instance Utrecht: Nico Slokker, Ruggengraat van de stad. De betekenis van gilden in Utrecht, 1528-1818 (Amsterdam 2009) 234; In 1814 the bakers of Groningen petitioned for the reintroduction of the guild system. Their guild at least continued to existed until 1828 , whereupon it was transformed into an association: GA, toegang 1325, 'Gilden, 1317-1883', inv.nr. 23, omslag 40-106. 


\section{Conclusion}

In this article I have argued that a local approach to the events of 1813 points to striking continuities with early modern civic traditions, most notably practices of civic republicanism and the persistence of a notion of local autonomy.

This has consequences for our understanding of the regime change of 1813. Given the reactions of the urban governments of Haarlem and Groningen to Gijsbert Karel van Hogendorp's initiative, one could argue that, in the eyes of contemporaries, his driemanschap (triumvirate) was a local initiative that only pretended to be the new national government in the name of the Prince of Orange. Although the driemanschap initiated a national power shift, the regime change started on the local level. Moreover, as the cases of Haarlem and Groningen show, the practical solutions to the crisis of ' 1813 ' were neither purely window dressing, nor provoked by a restoration agenda. On the contrary, urban citizens and governments smoothly switched between the many different practices and institutional legacies from the past and chose the one they regarded as the most suitable. Moreover, though the early modern corporative institutions were dismantled, the attached political discourse and practices affected Dutch local governance at least until the early years of the Kingdom of the Netherlands.

The persistence of early modern practices of civic republicanism also has something to teach us about continuity. One possible response to the discovery of previously unsuspected continuities is to argue that a previously perceived rupture, in this case the rupture between urban republicanism and national agency or an urban corporative society and the nation-state, did not happen until later. However, it may be more convincing to reconsider the nature of ruptures. In 1813 urban civic republicanism was not replaced by national agency, but adapted to the situation. The local pride and local organisation of voluntary civic militias during the crisis of 1830 and the local solutions to the imminent crisis of 1848 , suggest that in the first half of the nineteenth century republican traditions still influenced civic and governmental solutions to crises. Historians have noted that geographical identities (local, national, international, cosmopolitan) remained layered over a longer time. ${ }^{74}$ Probably notions of civic republicanism and national agency did as well. de Nederlandse identiteit, 1648-1815 (Nijmegen 2016); Remieg Aerts, 'Hoe nationaal was het Verenigd Koninkrijk? Over nationaal besef', in: Remieg Aerts and Gita Deneckere (eds.), Het
(On)Verenigd Koninkrijk, een politiek experiment in de Lage Landen, 1815-1830-2015 (Brussels 2015); Carolien Boender, 'Stedelijk patriottisme. Haarlem als centrum van de kosmos', in: ibidem, 95-102. 
Carolien Boender (1989) is a PhD candidate at Leiden University in the Nwo funded project The Persistence of Civic Identities in the Netherlands, 1747-1848. She investigates to what extent townspeople continued to rely on local civic traditions during the decades in which the national government became increasingly important. The cities of Haarlem and Groningen serve as case studies. Carolien Boender assisted the editorial board of the edited volume Een nieuwe staat. Het begin van het Koninkrijk der Nederlanden (Amsterdam 2013). She has published on the persistence of urban identities in the first half of the nineteenth century: 'Stedelijk patriottisme. Haarlem als centrum van de kosmos', in: Remieg Aerts and Gita Deneckere (eds.), Het (On) Verenigd Koninkrijk. Een politiek experiment in de Lage Landen, 1815-1830-2015 (Brussels 2015). Another article on Haarlem's memory culture, more specifically on how the Haarlemmerhout as a peripheral space was used, perceived and celebrated, will appear in Peter Clark and Denis Menjot, Subaltern City. Alternative and Peripheral Urban Spaces in the Pre-Modern Period (Turnhout, forthcoming).

Email: c.boender@hum.leidenuniv.nl. 